\title{
Analysis of the Impacts of Environmental Pollution of Pesticides on Oxidative Stress Profile in Liver and Kidney: A Case of Raid ${ }^{\circledR}$ in Wistar Rat
}

\section{Achudume AC*}

Institute of Ecology and Environmental Studies, Obafemi Awolowo University, Nigeria

\begin{abstract}
The widespread use of pesticides has numerous pathological consequences including agents which generate oxidative stress. Analysis of impacts of pesticides and oxidative stress provide available evidence that suggests changes that play a key role in various conditions which limit the human life span. Ingestion of insecticide Raid ${ }^{\circledR}$ was administered to wistar rats for 30 and 60 days and various target organs of rats were examined for oxidative stress profile. Results showed that all the parameters either in erythrocyte or the organs compared negatively with the control groups $(P<.05)$. The results indicated that catalase, superoxidedimutase (SOD), glutatathione reductase $(\mathrm{Gr})$, and glutathione (GSH) levels significantly decreased in rats treated with insecticide Raid ${ }^{\circledR}$ alone compared with the liver and kidney. Besides, raid-induced oxidative damage caused a significant increase in malondialdehyde (MDA) levels of the liver and kidney tissues. Even more disturbing is the fact that pesticide is typically associated with cellular dysfunction as discussed.
\end{abstract}

Keywords: Oxidative stress profile; Lipid peroxidation; Pesticides; Exposure routes; Insecticides; Raid ${ }^{\circledR}$

\section{Introduction}

Pesticides are ubitiquos and very prevalent in plant, everyone can be exposed to them just by walking on grass, drinking water and inhaling pollen in the air. Pesticides are equally found lurking in medicines, cosmetics and in just about everything. Residues of pesticides found in the air inside homes, on floors and other interior surfaces contribute to overall exposure of household occupants [1]. Additionally, open air burning of pesticides and application of it on the field are major contributors to environmental pollution problems. Some insecticides persist in the indoor environment or track-in. This is particularly true of DDT, chlordane and dieldrin whose efficiency depends on persistence [2]. Any of these chemicals may combine in the atmosphere to form fine particulate matters found in air (fruits and vegetables), water (sea foods), and in plant world (grains). Therefore, both wild life and humans are at risk from pesticide pollutions isn't the environment. Several reports have shown that pesticides of all kinds are cause of chronic degenerative diseases [3]. Pesticides and other chemicals have been shown to cause impaired reproduction [4], deformities [5], deficit in brain functions and are carcinogenic $[3,4,6]$, induce apoptosis and necrosis in human umbilical, embryonic, and placental cells [7] and other adverse health effects $[8,9]$.

A case of insecticide Raid ${ }^{\circledR}$ has widespread uses in control of insects especially anopheles mosquitoes [10]. However, because of chemical stability, insecticides Raid ${ }^{\circledR}$ accumulate rapidly in tissues causing death and have profound effect on growth [11]. Bioaccumulation factor of insecticide Raid ${ }^{\circledR}$ was observed in lipid, up to three times that of the feed at the first concentration while accumulation factor in the muscle , brain and liver was about the three times that of the feed [12]. There is little toxicity and bioaccumulation data for raid on rats in the literature. However, Davis et.al. [10] Presented summary of insecticide as having an acute dermal toxicity for rats, which is considered as extremely high.

In the past, accidental ingestion of pesticide was the primary method of supposed intake, but new studies show that inhalation and skin exposure are even higher. Understanding the levels, distribution of pesticides in the organs and subsequent overuse can aid environmental managers. The toxicity of $\operatorname{Raid}^{\circledR}$ on human oxidative stress is largely unknown, particularly how mixtures of pesticides by-products affect human toxicity. Restricting analyses to more homogeneous endpoints are important in characterizing human toxicity of pesticides. Therefore, the aim of the present studies is to explore critical window of exposure and target sites, while toxicity was examined for oxidative stress profiles using food (most important ingredient in health) as medium in liver and kidney.

\section{Materials and Methods}

\section{Test facility}

Tests with Wistar rats were conducted in a room temperature exposure facility $\left(23^{\circ} \mathrm{C}\right)$. Thirty-five animals weighing between 180 210 were caged in perforated aluminum chambers $(38 \times 55 \times 35 \mathrm{~cm})$. Five animals were placed in each of the chambers containing sawdust shaves, and a light: dark cycle of approximately $12 \mathrm{~h}$. Water was given ad libitum, temperature was maintained at $24 \pm 1^{\circ} \mathrm{C}$. Air temperature was $\pm 2^{\circ} \mathrm{C}$ of the water temperature. The animals were quarantined for 10 days before the beginning of the experiments. Protocols describing the use of animals in accordance with [13] National Research Council (NRC), a guide on the care and use of laboratory animals were maintained

\section{Test procedures}

Wistar rats were obtained from the animal breeding facility of College of Health Sciences, Obafemi Awolowo University, Ile-Ife, Nigeria. Technical grade RAID ${ }^{\circledR}$ (Johnson and Johnson), was dissolved in corn oil and in a rotary mixer 2:98 (w/w) with commercial feed,

${ }^{*}$ Corresponding author: Achudume AC, Institute of Ecology and Environmental Studies, Obafemi Awolowo University, Nigeria, E-mail: aachudum@yahoo.com

Received January 10, 2012; Accepted February 14, 2012; Published February 16,2012

Citation: Achudume AC (2012) Analysis of the Impacts of Environmental Pollution of Pesticides on Oxidative Stress Profile in Liver and Kidney: A Case of Raid ${ }^{\circledR}$ in Wistar Rat. J Environment Analytic Toxicol 2:124. doi:10.4172/2161-0525.1000124

Copyright: ( 2012 Achudume AC. This is an open-access article distributed unde the terms of the Creative Commons Attribution License, which permits unrestricted use, distribution, and reproduction in any medium, provided the original author and source are credited. 
Purina 5000, for $10 \mathrm{~min}$ : the control diet contained corn oil in the same proportion without Raid. Animals were fed raid-spiked commercial feed at measured concentrations of $25.0 \pm 2.4,54.0 \pm 9.2,108.0 \pm 12.5$, $216.0 \pm 14.6$, and $430.0 \pm 20.2$ and $961.0 \pm 80.6 \mu \mathrm{g} / \mathrm{g}$ 'Raid' for 10 days, increasing 5 - $10 \mathrm{~g} /$ day and ending with $96 \mathrm{~g} / \mathrm{rat}$. Three rats from different chambers receiving the same concentration of raid in the food were selected and tissue samples were dissected out (erythrocyte, kidney and liver) at test termination. The symptom-limited sensation tests were performed after an overnight fast. Mean values were calculated from the three rats sampled from each concentration of insecticide-raid.

\section{Measurement of body and organ weights}

Body, kidney and liver weights of the control and treated rats were measured at the end of the 30th and 60th days by employing an automatic balance (AND GX-600, Japan). Rats were anesthetized with diethyl ether after measurement of body weights, kidney and livers were removed and their weights were measured.

At test termination, blood was collected from retro-orbital plexus with the help of capillary tube $24 \mathrm{~h}$ after 30 and /or 60 days of exposure. Heparin $(2 \mathrm{mg} / \mathrm{ml})$ was used as an anticoagulant. Blood samples were centrifuged at $2000 \mathrm{rpm}$ for $15 \mathrm{~min}$ to separate plasma. The layer of white blood cells above the packed erythrocytes was discarded. Erythrocyte pellet was washed three times with $0.15 \mathrm{M} \mathrm{NaCl}$, diluted (33\%) in phosphate buffer saline ( $\mathrm{mM}: \mathrm{NaCl}, 136.9 ; \mathrm{KCl}, 2.68 ; \mathrm{KH}_{2}$ $\mathrm{PO}_{4}, 1.47$; and $\left.\mathrm{Na}_{2} \mathrm{HPO}_{4}, 6.62 ; \mathrm{pH} 7.4\right)$ and kept at $4^{\circ} \mathrm{C}$ until further analysis. The $33 \%$ packed erythrocytes were used for the estimation of LPO, GSH, Glutathione reductase, Catalase and Superoxide dismutase. LPO and GSH were measured on the day of blood collection.

\section{Measurement of LPO}

Lipid peroxidation (LPO) was assessed by measuring malondialdehyde (MDA) levels by thiobarbituric acid (TBA) reaction [14]. In brief, $0.2 \mathrm{ml}$ of $33 \%$ packed erythrocytes was incubated at $37 \pm 0.5^{\circ} \mathrm{C}$ for $2 \mathrm{~h}$. The sample was mixed with $1 \mathrm{ml}$ of $10 \% \mathrm{w} / \mathrm{v}$ trichloroacetic acid to precipitate protein. The mixture was centrifuged at $2000 \mathrm{rpm}$ for $10 \mathrm{~min}$ and an aliquot of $1 \mathrm{ml}$ supernatant was reacted with $1 \mathrm{ml}$ of $0.67 \%$ thiobarbituric acid in boiling water bath for 10 min. After cooling, it was diluted with $1 \mathrm{ml}$ of distilled water and the absorbance was read at $535 \mathrm{~nm}$. Results have been expressed as $\mathrm{n} \mathrm{mol} /$ $\mathrm{ml}$ packed erythrocytes.

\section{Assay of GSH level}

GSH content in erythrocytes was estimated by the method of [15] Prins and Loos (1969). Briefly, an erythrocyte pack of $0.2 \mathrm{ml}$ (33\%) was mixed with $4 \mathrm{ml}$ of $0.08 \mathrm{NH}_{2} \mathrm{SO}_{4}$. After $10 \mathrm{~min}, 0.5 \mathrm{ml}$ of tungstate solution was added and mixed vigorously for 5 min to clear the brown hemolysate. After allowing it to stand for $5 \mathrm{~min}$ to avoid crust formation on top of the supernatant, it was centrifuged for $15 \mathrm{~min}$ at $2000 \mathrm{rpm}$ at room temperature. Two milliliters of supernatant was mixed with $2.5 \mathrm{ml}$ of Tris buffer $(\mathrm{pH} 8.0)$ and $0.2 \mathrm{ml}$ of 5, 5' -dithiobis2 -nitrobenzoic acid reagent. Within a minute, absorbance was read at $412 \mathrm{~nm}$. The levels of GSH have been expressed as $\mathrm{mmol} \mathrm{GSH} / \mathrm{ml}$ packed erythrocytes.

\section{Determination of SOD activity}

SOD activity was determined by the procedure of [16] Madesh and Balasubramanian (1998). The reaction mixture contained $0.65 \mathrm{ml}$ PBS ( $\mathrm{pH}$ 7.4), $30 \mu \mathrm{l}$ 3-(4-5 dimethyl thiazol 2-xl) 2, 5-diphenyl tetrazolium bromide (MTT; $1.25 \mathrm{~mm}), 75 \mu \mathrm{l}$ pyrogallol $(100 \mu \mathrm{M})$, and $10 \mu \mathrm{l}$ hemolysate (10\%). The mixture was incubated at room temperature for $5 \mathrm{~min}$, and the reaction was stopped by adding $0.75 \mathrm{ml}$ of dimethyl sulfoxide. The absorbance was read at $570 \mathrm{~nm}$ and the activity has been expressed as Unit. One unit of SOD was defined as the micrograms of hemoglobin causing 50\% inhibition in the MTT reduction.

\section{Determination of catalase activity}

Catalase activity in erythrocytes was assayed by the spectrophotometric method of [17]. In brief, $2 \mathrm{ml}$ of phosphate buffer $(50 \mathrm{mM}, \mathrm{pH} 7.0)$ and $10 \mu \mathrm{l}$ hemolysate (10\%) were taken in a curvette. Reaction was started by adding $1 \mathrm{ml} \mathrm{H}_{2} \mathrm{O}_{2}(10 \mathrm{mM})$ and the absorbance was recorded at every $10 \mathrm{sec}$ for $1 \mathrm{~min}$ at $240 \mathrm{~nm}$ against water blank. The activity of catalase has been expressed as $\mathrm{mmol} \mathrm{H}_{2} \mathrm{O}_{2}$ utilized/min/ mg hemoglobin.

\section{Determination of GR activity}

GR activity was measured following the method of [18]. The $3 \mathrm{ml}$ of reaction mixture contained $2.6 \mathrm{ml}$ PBS $12 \mathrm{M}$, pH 7.2), $0.1 \mathrm{ml}$ EDTA $(15 \mathrm{mM}), 0.1 \mathrm{ml}$ oxidized glutathione (GSSG) $(65.3 \mathrm{mM})$. To this, $10 \mu \mathrm{l}$ of hemolysate was added and the volume was made up to $2.95 \mathrm{ml}$ with distilled water. After incubation at room temperature for $5 \mathrm{~min}, 0.05$ $\mathrm{ml}$ of NADPH $(9.6 \mathrm{mM})$ was added. Decrease in absorbance/min was recorded immediately at $340 \mathrm{~nm}$ for $3 \mathrm{~min}$. Control was run without GSSG. The activity of GR has been expressed as unit/g hemoglobin. One unit is $\mu \mathrm{mol} \mathrm{NADPH}$ utilized $/ \mathrm{min} / \mathrm{g}$ hemoglobin.

Estimation of Hemoglobin in erythrocytes was determined by using kits (BDH Chemical, England) following the manufacturer's recommendations.

\section{Statistical analysis}

All values have been expressed as mean \pm SEM. Two-way analysis of variance followed by Duncan's post-hoc test was used to find out the differences between mean values. The differences were considered significant when $p<0.05$.

\section{Results}

Lipid peroxidation and oxidative profile of male rats exposed to insecticide Raid ${ }^{\mathbb{B}}$ in erythrocyte, liver and kidney is shown in Table 1. The data show that Raid ${ }^{\circledR}$ has no effect on the antioxidants on the erythrocyte, liver and kidney when administered for thirty days. It is equally observed that all oxidative profiles were decreased after 60 days. All the parameters either in erythrocyte or the organs compared nagatively with the control groups $(\mathrm{P}<.05)$. The results indicated that catalase, SOD, Gr, and GSH levels significantly decreased in rats treated with insecticide Raid $^{\circledR}$ alone compared with the liver and kidney. Besides, raid-induced oxidative damage caused a significant increase in MDA levels of the liver and kidney tissues. More so, rats exposed for 60 days increased lipid peroxidation level by $2.0 \%$ of the control these effects are marked for reduced glutathione which decreased by $2.4 \%$ for 30 days and $5 \%$ for 60 days respectively. In the liver, insecticide Raid ${ }^{\mathbb{B}}$ could not produce any significant changes in the magnitude of LPO and glutathione reductase levels respectively, but show some activities in catalase $(0.75 \%)$, SOD $(0.23 \%)$, reduced glutathione $(0.07 \%)$, i.e when rats are exposed for 30 days. However, after 60 days of exposure, Raid $^{\circledR}$ caused significant increased in LPO $(10.3 \%) \mathrm{p}<0.05$, diminution in the activities of catalase (5.5\%), SOD (9.5\%), GR ( $8.5 \%)$, and reduced glutathione (12\%) levels. In the kidney the effect of insecticide is less marked in MDA (1.3\%), whereas, there are decreases in catalase $(0.6 \%)$, SOD (0.7\%), GR (1\%) and reduced glutathione (1.3\%) for 30 days. 


\begin{tabular}{|c|c|c|c|c|c|}
\hline $\begin{array}{c}\text { Blood } \\
\text { Erythrocyte }\end{array}$ & $\begin{array}{c}\text { Lipid } \\
\text { peroxidation }\end{array}$ & Catalase & $\begin{array}{l}\text { Superoxide } \\
\text { dismutase }\end{array}$ & $\begin{array}{c}\text { Glutathione } \\
\text { reductase }\end{array}$ & $\begin{array}{c}\text { GSH } \\
\text { (glutathione) }\end{array}$ \\
\hline Control & $4.88(0.28)$ & $89.73(2.84)$ & $4.28(0.16)$ & $14.24(0.84)$ & $0.42(0.03)$ \\
\hline 30 days & $4.89(0.11)$ & $89.72(2.60)$ & 4.2990 .200 & $14.25(0.07)$ & $0.41(0.92)$ \\
\hline 60 days & $4.98(0.18)^{*}$ & $89.05(2.42)^{*}$ & $4.21(0.18)^{*}$ & $14.24(0.01)^{*}$ & $0.40(0.13)^{*}$ \\
\hline Liver cont & $4.52(0.37)$ & $89.12(2.03)$ & $4.36(0.17)$ & $14.19(1.37)$ & $0.47(0.25)$ \\
\hline 30 days & $4.52(0.20)$ & $88.37(1.87)$ & $4.31(0.15)$ & $14.18(0.08)$ & $0.46(0.14)$ \\
\hline 60 days & $5.04(0.62)^{*}$ & $84.45(3.00)^{*}$ & $3.98(0.17)^{*}$ & $13.08(0.02)^{*}$ & $0.42(0.26)^{*}$ \\
\hline Kidney cont & $3.96(0.52)$ & $78.24(0.96)$ & $4.08(0.08)$ & $14.50(0.21)$ & $3.09(0.01)$ \\
\hline 30 days & $4.01(0.34)$ & $77.81(2.65)$ & $4.05(0.69)$ & $14.34(0.22)$ & $3.05(0.04)$ \\
\hline 60 days & $5.24(0.65)^{\star}$ & $76.88(0.12)^{*}$ & $3.98(0.23)^{*}$ & $13.24(0.57)^{*}$ & $3.08(0.02)$ \\
\hline
\end{tabular}

Lipid peroxidation: nmol malondialdehyde/ml packed erythrocytes; Catalase: $\mathrm{nmol} \mathrm{H}_{2} \mathrm{O}_{2}$ utilized/min/mg hemoglobin; Superoxide dismutase: One unit is $\mu \mathrm{g}$ hemoglobin required to inhibit 3-(4-5 dimethyl thiazol 2-xl) 2, 5-diphenyl tetrazolium bromide reduction by $50 \%$; Glutathione reductase: $\mu$ mol NADPH utilized/min/g hemoglobin. ( ) Values represent mean $\pm \operatorname{SE}(n=3) .{ }^{*} p<0.05$ compared to control

Table 1: Lipid peroxidation and antioxidative systems in erythrocytes, liver and kidney of male rats exposed to insecticide Raid ${ }^{\circledR}$ for 30 days and /or 60 days.

While at 60 days, rats exposed for $60 \%$ showed pronounced effects in the increased level of malondialdehyde (24\%) and diminution in the levels of SOD (1.7\%), GR (2.5\%) and glutathione reductase (1.8\%).

\section{Discussion}

From the data presented in table 1 it is apparent that the insecticide Raid $^{\circledR}$ is central to all the complex multifaceted reactive system, where there is substantial decreases in the inter-dependence between separate organ component members i.e. the malondialdehyde, catalase, Superoxide dismutase, glutathione reductase and glutathione. Glutathione complex participates in detoxification at several different levels, and may be responsible for various increases in malondialdehyde and the decreases in oxidative profiles of the rat scavenging for free radicals against Raid $^{\circledR}$ toxic products.

Increases in the intracellular levels of pesticides, if not contained may lead to membrane dysfunction and inactivation of proteins compounds. Thus, the antioxidant responsive elements found in cells and organs are inducible by oxidative and chemical stress [19]. These antioxidants provide the multiple defenses against frequently and potentially reactive oxygen species (ROS), enhanced antioxidant and detoxification capacity of normal cells may be affected by many pesticides agents. Chronic oxidative stress has numerous pathological consequences including cancer [20], arthritis and neurodegenerative disease [4]. For example, the decreases observed in the oxidative profile of rats after exposure to insecticide Raid $^{\circledR}$ is associated with the major mechanism for cellular protection against agents which generate oxidative stress.

Many pesticides are hydrophobic molecules that connect extensively to biological membranes, particularly to the phospholipids bilayers [21] and in lipid-rich internal tissues including body fat, liver, kidney, and elements of the central and peripheral nervous system [22]. They may damage the membranes by inducing lipid peroxidation that may have led to accumulation of malondialdehyde. Erythrocytes are more vulnerable to LPO [23]. Lipid peroxidation has been shown to cause profound alterations in the structure and functions of the cell membrane including decreased membrane fluidity, increased membrane permeability, inactivation of membrane-bound enzymes, and loss of essential fatty acids [21]. This kind of pesticides may also cause serious adverse impact to non-target organisms and humans [24]. The primary toxicity of these pesticides may therefore be due to irreversible inhibition of lipid peroxidation [25]. The bottom line is that humans regularly interact with countless pesticides substances that could trigger illness on a daily basis. This underscores the importance of living life as purely as possible. What it means is that, since these environmental pollutions of pesticides are so common and widespread, virtually everyone could be at risk. Environmental pesticide must also be a concern for those predisposed to an auto-immune disease.

Among common pesticides, organophosphorus (OP) compounds are used in the industry as softening agents, hydraulic liquids, additives to lubricants and antioxidants. They are used in agriculture as pesticides, insecticides, and acaricides; and in home as chemical cleaning agents [26]. Wide range application of pesticides can lead to penetration of pesticides into hydrological systems or contamination of food crops. Furthermore, pesticides are known to cause inhibition of pseudo-cholinesterase activity [27]. According to recent studies, many organs such as the heart [25], the kidney [28], the pancreas [29], the liver [30], the reproductive system [31], hematological and biochemical parameters [30] could be affected by pesticide toxicity. These damages cause inflammation leading to mitochondrial toxicity [32] and dysfunctional mitochondria enhance susceptibility to cell death [33], tissue impairment sets in followed by pathology.

Several other studies with cell cultures or experimental animals have shown that the oxidative shift in the intracellular glutathione (redox status) is typically associated with cellular dysfunction $[34,35]$. Complementary studies in human have shown that oxidative changes in the plasma (i.e., extracellular) are correlated with aging-related patho-physiological processes [36]. The available evidence suggests that these changes play key role in various conditions which limit the human life span [35]. Such theories claim that oxidative stress within mitochondria can lead to a vicious cycle in which damaged mitochondria produce increased amounts of reactive oxygen species, leading in turn to progressive augmentation in damage cell [36]. For example, the widespread use of glyphosate, the active ingredient in the herbicide Roundup, is exacerbating the problem. Glyphosate immobilizes certain nutrients, rendering them inaccessible to the plant, which in turn robs of essential micronutrients normally from food. It also cannot be washed off, as it is absorbed systemically through the plant, which means consumption of herbicide is far more than ever imagined. Besides, glyphosate-induced oxidative damage caused a significant decrease in GSH levels and a significant increase in MDA levels of the liver and kidney tissues [37]. Glyphosate is suspected of causing genetic damage [5], infertility and cancer [38]. It is also acutely toxic to fish and birds and can kill beneficial insects and soil organisms that maintain ecological balance. 
Citation: Achudume AC (2012) Analysis of the Impacts of Environmental Pollution of Pesticides on Oxidative Stress Profile in Liver and Kidney: A Case of Raid ${ }^{\circledR}$ in Wistar Rat. J Environment Analytic Toxicol 2:124. doi:10.4172/2161-0525.1000124

\section{References}

1. Lewis RG, Bond AE, Fortman RC, Camann DE (1994) Evaluation of the methods for monitoring the exposure of small children to pesticides in the residential environment. Arch Environ Contami Toxicol 26: 37-46.

2. Nebeker AV, Dunn KD, Griffis WL, Schuytema GS (1994) Effects of dieldrin in food and growth and bioaccumulation in Mallard ducklings. Arch Environ Contam Toxicol 26: 29-32.

3. Relyea RA (2005) The lethal impact of Roundup on aquatic and terrestrial amphibians. Ecological Applications 15: 1118-1124.

4. Huffington Post (2010) Genetically modified soy linked to sterility, infan mortality in hamsters.

5. Dallegrave E, Mantese FD, Coelho RS, Pereira JD, Dalsenter PR, et al. (2003) The teratogenic potential of the herbicide glyphosate-roundup ${ }^{\circledR}$ in Wistar rats. Toxico lett 142: 45-52.

6. Arbuckle TE, Lin Z, Mery LS (2001) An explanatory analysis of the effect of pesticide exposure on the risk of spontaneous abortion in an Ontario farm population. Environ Health Perspect 109: 851-857.

7. Benachour N, Seralini GE (2009) Glyphosate formulations induce apoptosis and necrosis in human umblical, embryonic, and placental cells. Chem Res Toxicol 22: 97-105

8. Swan SH (2008) Environmental phthalate exposure in relation to reproductive outcomes and other health endpoints in humans. Environ Res 108: 177-184.

9. Edge CB, Gahl MK, Pauli BD, Thompson DG, Houlahan JE (2011) Exposure of juvenile green frogs (Lithobates clamitans) in littoral enclosures to a glyphosatebase herbicide. Ecotoxicol Environ Safety 74: 1363-1369.

10. Davis G, Hickox WH, Helliker PE (1996) Summary of pesticide use report data. State of California. E.P.A Sacramanto, $\mathrm{Ca}$

11. Achudume AC, Nwoha PC, Ibe JN (2009) Toxicity and Bioaccumulation of the Insecticide "Raid" in Wistar Rats. International Journal Environmental Toxicity 24: $357-361$

12. Achudume AC, Nwoha PU, Ibe JN (2010) Effects of dietary exposure to insecticide Raid ${ }^{\circledR}$ on survival, growth and inhibition of metabolic processes in Wister rats. Intern. J Environ Chem And Ecotoxicol 2: 120-125.

13. (1996) National Guide for the Care and Use of Laboratory Animals. Washington DC: Research Council, The National Academies Press.

14. Heath RL, Packer L (1968) Photoperoxidation in isolated chloroplasts. Kinetics and stoichemistry of fatty acid peroxidation. Arch Biochem Biophys 125: 189198

15. Prins HK, Loos JA (1969) Glutathione. In: Yunis JG (ed) Biochemical methods in red cell genetics. Academic Press, New York 127-129

16. Madesh M, Balasubramanian KA (1998) Mirotiter plate assay for superoxide dismutase using MIT reduction by superoxide. India J Biochem Biophys 35: 184-188.

17. Aebi H (1984) Catalase in vitro, Methods in Enzymology 105: 121-126

18. Goldberg DM, Spooner RJ (1983) Glutathione reductase. In: Bergmeyer HU, Bergmeyer J, GraBI M (ed) Methods of enzymatic analysis, $3^{\text {rd }}$ ed., vol. III. Verlag Chemie, Weiheim 258-265

19. Garcia SJ, Abu-Qare AW, Meeker-O'Connell WA, Borton AJ, Abou-Donia MB (2003) Methyl Parathion: A review of health effects. J Toxicol Environ Health B Crit Rev 6: 185-210.

20. Johnston-Cox HA, Ravid K (2011) Adenosine and blood platelets. Purinergic Signal 7: 357-365.

21. Van Ginkel G, Sevanian A (1994) Lipid peroxidation-induced membrane structural alterations. Methods Enzymology 233: 273-288.

22. Kassa J (2002) Review of oximes in the antidotal treatment of poisoning by organophosphorus nerve agents. Clin Toxicol 40: 803-816.

23. Eritsland J (2000) Safety considerations of polyunsaturated fatty acids. Am Journal Clinical Nutrition 71: 197 S-201S.

24. Wu J, Lin L, Luan T, Chan Gilbert YS, Lan C (2007) Effects of organophosphorus pesticides and their ozonation byproducts on gap junctional intercellular communication in rat liver cell line. Food Chem Toxicol 45: 2057-2063.
25. Ogutcu A, Uzunhisarcikli M, Kalender S, Durak D, Bayrakdar F, et al. (2006) The effects of organophosphate insecticide diazinon on malondialdehyde levels and myocardial cells in rat heart tissue and protective role of vitamin $\mathrm{E}$. Pestic Biochem Physiol 86: 93-98.

26. Gbaruko BC, Ogwo El, Igwe JC, Yu H (2009) Organophosphate induced chronic neurotoxicity: Health, environmental and risk exposure issues in developing nations of the world. Afr J Biotechnol 8: 5137-5141.

27. Kalender Y, Uzunhisarcikli M, Ogutcu A, Acikgoz F, Kalender S (2006) Effects of diazinon on pseudocholinesterase activity and haematological indices in rats: the protective role of vitamin E. Environ Toxicol Pharmacol 22: 46-51.

28. Kalender S, Kalender Y, Durak D, Ogutcu A, Uzunhisarcikli M, et al. (2007) Methyl parathion induced nephrotoxicity in male rats and protective role of vitamins C and E. Pestic Biochem Physiol 88: 213-218.

29. Gokalp O, Buyukvanlı B, Cicek E, Ozer K, Koyu A, et al. (2005) The effects of diazinon on pancreatic damage and ameliorating role of vitamin $E$ and vitamin C. Pestic Biochem Physiol 81: 123-128.

30. Kalender S, Uzun FG, Durak D, Demir F, Kalender Y (2010) Malathion-induce hepatotoxicity in rats: The effects of vitamin $C$ and $E$. Food Chem Toxicol 48 : 633-638

31. Uzun FG, Kalender S, Durak D, Demir F, Kalender Y (2009) Malathion-induced testicular toxicity in male rats and the protective effect of vitamins $C$ and $E$. Food Chem Toxicol 47: 1903-1908.

32. Wei YH, Lu CY, Wei CY, Ma YS, Lee HC (2001) Oxidative stress in human aging and mitochondrial disease consequences of defective mitochondria respiration and impaired antioxidant enzyme system. Chin J Physio 44: 1-11.

33. Serviddio G, Romano AD, Cassano T, Bellanti F, Altomare E, et al. (2011) Principles and therapeutic relevance for targeting mitochondria in aging and neurodegenerative diseases. 17: 2036-2055

34. Hayes JD, McLellan LI (1999) Glutathione and glutathione-dependent enzymes represent a co-ordinately regulated defence against oxidative stress. 31: 273 300

35. Dröge W (2003) Oxidative stress and aging. Adv Experim Med Bio 543: 191 200.

36. Romano AD, Serviddio G, de Matthaeis A, Bellanti F, Vendemiale G (2010) Oxidative stress and aging. J Nephrol 15: S29-S36.

37. Waltz E (2010) Glyphosate Resistance Threaten Roundup Hegemony. Nat Biotechnol 28: 537-538.

38. Cavuşoğlu K, Yapar K, Oruç E, Yalçın E (2011) Protective Effect of Ginkgo biloba L. Leaf Extract Against Glyphosate Toxicity in Swiss Albino Mice. J Med Food 14: 1263-1272.

39. Lowry OH, Rosebrough NJ, Ferr AL, Randall RJ (1951) Protein measurement with folin phenol reagent. J Biol Chem 193: 265-275. 